\title{
FACULTY AND ADMINISTRATOR VIEWS OF INFLUENCES ON PROFESSIONAL PROGRAMS
}

\author{
Joan S. Stark, Malcolm A. Lowther, and Bonnie M. K. Hagerty
}

Administrators in professional programs perceive influences on the program from within the university as stronger than do faculty but the two groups do not perceive the strength of societal influences, professional community influences, or internal levels of curriculum debate differently. After controlling for program and institutional sizes and institutional types, these differences between faculty and administrator views regarding relationships between the program and the university appear characteristic of certain professional fields. The analysis was based on subsamples drawn from a data base of survey responses from 873 administrators and 849 faculty members in ten professional fields representing $\mathbf{7 3 2}$ programs in $\mathbf{3 4 6}$ colleges and universities.

Differing views about organizational matters between administrators and other employees are found in all institutions, even in colleges where faculty typically play a collegial role in governance and have considerable autonomy over their work. In higher education, comparisons of these varying perspectives usually have focused on reward systems, faculty working conditions, and the distribution of power and authority in governance. Some studies have compared faculty and administrator views about broad institutional goals and associated power relationships (e.g., Gross and Grambsch, 1974), but few comparisons have been made of faculty and administrator views about influences and trends that directly affect educational activities at the academic program level.

Research about the academic administrative role has centered on tasks and dimensions of leadership performance as perceived by both department chairs and faculty (Knight and Holen, 1985; McLaughlin, Montgomery and Sullins, 1977) or on such issues as the effect of department head performance on faculty morale (Madron, Craig, and Mendel, 1976). While there is considerable

Joan S. Stark, Malcolm A. Lowther, and Bonnie M. K. Hagerty, Center for the Study of Higher and Postsecondary Education, The University of Michigan. Address correspondence to: Joan S. Stark, 2400 School of Education, The University of Michigan, Ann Arbor, Michigan 48109-1259. 
controversy over whether deans and department chairpersons think like faculty members or like managers, there is general agreement that they play important roles as "persons in the middle," looking both toward the faculty and toward the administration while representing the views of each group to the other (Bennett, 1983; Whitson and Hubert, 1982). A variety of role-related tensions are believed to arise from the need to create a bridge between faculty and administration (Bennett, p. 2), to monitor the flow of information in land out of the department (McLaughlin, Montgomery and Sullins, 1977), or to resolve tensions among subunits within the department or college (Ryan, 1980).

When faculty members become chairpersons, they may also become entrepreneurs (Bennett, p. 168) and politicians (ibid., p. 174). Additionally, they are assumed to undergo several conceptual transitions: (1) from specialist to generalist; (2) from individualism to collectivism, and (3) from disciplinary loyalist to institutional loyalist (Bennett, pp. 3-5). Compared to faculty, academic administrators may face additional dilemmas: relating broadly to external reference groups, considering long-range as well as short-range organizational tasks, and acquiring and using resources effectively (Stark, 1986). In short, the academic administrator is concerned with the institution's adaptive system as well as its maintenance system (Katz and Kahn, 1966).

Despite assertions that leaders should attend to factors in the external environment, the interface between university programs and influencers outside the university may have low priority among academic administrators. Based on a survey of roles and satisfactions of department chairs in 32 state universities, McLaughlin, Montgomery, and Malpass (1975) empirically derived three major roles of the department chair: the academic role (encompassing relationships with students, research, and curriculum development); the administrative role (including budgeting, record keeping, and maintaining linkages with the rest of the university); and leadership (involving personnel relations and program development). Interestingly, the dimensions of this taxonomy appear not to include specific attention to external influences. In a similar survey, Whitson and Hubert (1982) found that, relative to forces within the university, academic administrators did not see external groups as strongly influencing their managerial decisions. They noted, however, that administrators in professional fields were more likely than other administrators to acknowledge important external influences. Similarly, Gross and Grambsch (1974) noted that professional school deans in the large research universities they studied were likely to have strong and powerful interaction networks external to the campus.

While some researchers have emphasized the commonality across departments of the various academic or administrative competences required of academic administrators (Jennerich, 1981), others have noted that the discipline has an impact on the role a chairperson plays (Smart and Elton, 1976). In particular, evidence suggests differences in the department chairperson role or 
leadership style in some professional study fields such as agriculture and business when compared to arts and science departments (McLaughlin et al., 1977; Gross and Grambsch, 1974). In general, however, while noting these findings, researchers studying roles and perceptions of academic administrators have continued to view professional fields as a homogeneous group (see Whitson and Hubert, 1982) or to divide administrators by level of administration rather than by field of study (Gross and Grambsch).

It is clear, however, that collegiate professional programs are not homogeneous in their relationships with society and the university but rather differentially sensitive to a variety of influences. By adapting a Carnegie Foundation list of internal and external influences that affect undergraduate curricula, we developed and published a framework positing three sets of influences specifically expected to shape professional programs (Stark et al., 1986b). In this scheme, external influences include such factors as labor market cycles, changes in external licensing standards, varying government funding policies, and media portrayals of professional practice. Internal influences include such factors as the general orientation of faculty members toward scholarly work and professional practice, the nature and developmental stage of the various knowledge bases contributing to practice, the types of students selecting study, and the extent to which professional practice settings are controlled directly by the program. Finally, we defined intraorganizational influences as factors originating within the university but external to the program, such as resource allocation processes and governance procedures. Subsequently, we have demonstrated that varying perceptions of the strength of external influences uniquely characterize academics in several professional fields (Stark, Lowther, and Hagerty, 1987).

The field-specific situations leading to different perceptions among professional program faculty reinforce the need for academic administrators to respond to unique external influences; for example, alumni, government agencies, employers of graduates, and specialized accrediting agencies. Since such external influences may help to shape behavior in the academic, administrative, and leadership roles outlined by McLaughlin et al. (1975), a complete taxonomy of roles for the professional dean or department chair might include greater attention to the origin of influences: outside the college or university, outside the department but within the university, and within the department.

As those responsible for external linkages and leadership activities, academic administrators may exhibit keener awareness of external influences than do faculty. Furthermore, since they must uphold the image of the academic unit in institutional forums, administrators may develop and communicate more positive or optimistic views of the unit's status or prospects within the institution than do faculty. In contrast, faculty members may be more familiar with and 
concerned about internal academic discussions and perhaps less attentive to university support and external linkages. Using data aggregated across academic and professional departments in a restricted sample of universities, Gross and Grambsch (p. 172) concluded that faculty and administrators held basically similar perceptions of broad university goals or power relationships. Similar comparisons of perceptions between faculty and administrators have not been made for specific professional programs, nor have comparisons focused on goals and influences at the program level. Based on available survey data containing faculty and administrator views of influences and curriculum debates in several different professional programs nationally, this study explores faculty and administrator views about program-related matters.

\section{PURPOSES OF THE STUDY}

Four propositions appear plausible from previous research on the roles, tasks, and perceptions of academic administrators: (1) academic administrators may perceive external forces upon their teaching fields as more influential than do faculty; (2) academic administrators may perceive intraorganizational forces (from within the university) as stronger than do faculty; (3) faculty members may perceive internal influences as stronger than do administrators; and (4) the patterns of difference between faculty members and administrators may vary by professional field.

\section{METHOD}

\section{Data Source}

The existing survey data were designed to compare perceptions of faculty members in different professional programs about influences affecting their educational efforts. Responses were available from a nationwide survey of faculty and administrators in eleven types of programs, namely, undergraduate programs in architecture, business administration, education, engineering, journalism, nursing, pharmacy, and social work, and entry-level graduate programs in law, library science, and social work. These fields were chosen to include an illustrative and diverse set of entry-level professional programs found at a wide variety at U.S. colleges and universities of varying types and sizes. The population for the 1985 survey included 1,814 accredited and nonaccredited programs from the above fields in 551 U.S. colleges and universities (Carnegie classifications - research universities, doctoral universities, and comprehensive colleges and universities I). The sampling unit was the professional study program, each stratified separately by institutional type, control, and predicted regional enrollment decline. The randomly drawn survey sample included 1,046 
programs; a 50\% sample from each cell for the most frequently offered programs and a $100 \%$ sample from each cell for less common programs.

Since no source accurately identifies the population of all faculty teaching in these entry-level programs, program administrators (deans or department chairpersons) were identified and asked to respond. They were also asked to request responses from a number of faculty (proportional to the program's annual degree production) who, in their judgment, were closely involved in the preservice professional preparation program. Sampling was designed to survey 4.65 individuals in the program of mean size in each study field.

The 2,217 timely and useable responses from 732 of the 1,046 programs represents a response rate of $69.8 \%$ of solicited programs. The program response rate by field varied from $56 \%$ to over $95 \%$, and responding programs, located in 346 different institutions, closely resembled the survey population. Retest reliability data $(N=187)$ gathered seven months later showed little variation in response.

\section{Nature of the Survey Questions}

The survey questions regarding influences on professional programs were answered on seven-point Likert-type scales $(1=$ strongly disagree to $7=$ strongly agree) in the context of the general statement: "Professional preparation programs are subject to a variety of influences from within and without the university or college." For external influences, the specific context statement was: "We are interested in determining if faculty members believe certain influences affect their professional field . . . please circle the number which indicates the extent to which you agree or disagree that the statement is true for your field at the current time, 1984-85." Illustrative external influence statements to which respondents indicated their agreement or disagreement are: "Society provides ample rewards for members of the professional field," and "Government agencies provide sufficient funding for professional preparation or training programs."

For intraorganizational influences, the context statement read: "The following items refer to influences which are external to the professional preparation program but originate within the university. Answer in the same manner as for the questions you have just finished, but use as your reference point your program in your university or college. Examples include: "The program is closely interconnected with other programs in the university (college)." and "Financial support to the program provided by the university (college) is adequate."

Finally, because of the difficulty of writing survey items to tap specific internal influences, the extent to which the program was engaged in various curricular debates was used as a proxy for internal influences on professional 
programs. The context statement read: "Most educational programs in colleges and universities are characterized by some degree of controversy, debate, or ferment about what the curriculum should be and how it should be executed. Sometimes these debates are viewed as healthy and productive; sometimes they are seen less positively. To what extent do you believe each of the following curricular debates exist in your professional program in your college or university during the 1984-85 academic year?" Examples of statements in this section of the survey include: "Debate or controversy concerning the content of supporting studies in liberal or general education," and "Debate or controversy concerning entrance or admission requirements for students." Responses ranged from $1=$ no debate to $7=$ much debate. Although pilot tests with professional field faculty and administrators indicated the face validity of this proxy measure, the actual correspondence of curricular debates with internal influence is unknown.

\section{Plan of Analysis}

The two primary research questions were:

1. Do professional program faculty members and administrators differ in the strength they attribute to external, intraorganizational, and internal influences affecting their programs?

2. If differences in faculty and administrator views are identified, do they occur consistently among professional programs?

Hierarchical multiple regression was the method of analysis. Using a randomly drawn sample of equal numbers of respondents from each professional field, four regression equations were examined. In each equation, the dependent variable was a factor score representing the perceived strength of one of four type of influences: external influence (societal or professional community), intraorganizational influence, or internal influence. After controlling for relevant covariates (institutional and program size and type), professional field identification and role as a faculty member or administrator were allowed to enter the equation as dummy predictor variables in alternating order. For those regression models in which faculty or administrative role appeared to predict influence perceptions differentially among professional fields, the set of responses from each professional field in the larger data base was regressed separately on the covariates and the independent variable, faculty/administative role.

\section{Analysis Sample}

Survey respondents were asked to select their administrative title from a list of commonly used designations or to indicate that they held no administrative 
title. Unfortunately, there is neither consistent practice in assigning academic administrative titles nor useful classifications in the literature. Some investigators have grouped chairpersons and deans together as administrators exercising responsibilities within a college (McLaughlin et al., 1977). In contrast, others perceive deans to far exceed chairpersons in the authority hierarchy and have not combined the two groups (Zey-Ferrell and Ervin, 1985). In this study we grouped deans, associate deans, department chairpersons, and program coordinators as academic administrators for two reasons: (1) individuals with professional program responsibilities might hold any one of the administrative titles depending on the size and nature of the institution, and (2) at our request the academic administrator with most direct responsibility for the entry-level academic program completed the survey, regardless of title.

Based on these considerations, 2,010 individuals were designated as either faculty members or administrators. The 1,010 individuals classified as academic administrators reported the following titles: dean (228), associate or assistant dean (156), department chair (352), and program coordinator (274). Overall $50.2 \%$ of the survey respondents were classified as faculty and $49.8 \%$ as administrators, but these percentages varied substantially for different professional fields. In fields with many programs located in small institutions (e.g. business, education), the percentage of faculty was as low as $42.1 \%$. In other fields, where administrative scope was broad or program size large, the percentage of faculty was greater (e.g., library science, $67.2 \%$; law, 61.6\%). Since responses were sought from an administrator in every sampled program but from only a fraction of faculty in these programs, the data base contains a random and representative sample of program administrators in the eleven fields, but the sample of faculty is neither random nor proportional to the actual faculty numbers.

Table 1 presents a comparison of the demographic characteristics of those classified as either faculty or administrators in each of the eleven types of programs as well as the characteristics of the institutions and programs from which the samples of faculty and administrators were drawn. In addition to administrative title variations, it is clear from Table 1 that age, experience, teaching assignments, academic rank, and gender distribution of faculty and administrators differ among the various professional fields. In five of the eleven types of programs, administrators were significantly older than faculty and in seven fields they had more years of faculty experience. As might be expected, in every field administrators saw the administrative role as considerably more important than did faculty. At the same time, in six of eleven fields administrators valued the teaching role to the same extent as did faculty, but they reported spending less time in teaching (except for pharmacy and undergraduate social work). In all fields except undergraduate social work, administrators tended to hold higher academic rank than faculty and, except in 
TABLE 1. Demographic Characteristics of Faculty, Administrators, and Programs

\begin{tabular}{|c|c|c|c|c|c|c|c|c|}
\hline \multirow[b]{2}{*}{ Characteristics } & \multicolumn{2}{|c|}{ Architecture } & \multicolumn{2}{|c|}{ Business } & \multicolumn{2}{|c|}{ Education } & \multicolumn{2}{|c|}{ Engineering } \\
\hline & $\begin{array}{l}\text { Faculty } \\
N=43\end{array}$ & $\begin{array}{l}\text { Admin. } \\
N=40\end{array}$ & $\begin{array}{l}\text { Faculty } \\
N=107\end{array}$ & $\begin{array}{l}\text { Admin. } \\
N=147\end{array}$ & $\begin{array}{l}\text { Faculty } \\
N=172\end{array}$ & $\begin{array}{l}\text { Admin. } \\
N=234\end{array}$ & $\begin{array}{l}\text { Faculty } \\
N=100\end{array}$ & $\begin{array}{l}\text { Admin. } \\
N=102\end{array}$ \\
\hline Percent in role & 51.8 & 48.2 & 42.1 & 57.9 & 42.4 & 57.6 & 49.5 & 50.5 \\
\hline Age & 44.8 & 48.3 & 44.7 & 47.7 & 47.5 & 50.2 & 48.7 & 50.8 \\
\hline Years faculty & 10.9 & 17.3 & 11.8 & 16.6 & 14.2 & 16.9 & 18.4 & 20.5 \\
\hline Teaching time $^{a}$ & 11.1 & 8.5 & 10.8 & 7.4 & 12.2 & 8.4 & 10.5 & 7.5 \\
\hline \multicolumn{9}{|l|}{ Teaching role } \\
\hline $\begin{array}{l}\text { Administrative } \\
\text { role important }{ }^{b}\end{array}$ & 2.3 & 4.3 & 2.0 & 3.2 & 2.3 & 5.2 & 2.3 & 4.9 \\
\hline \multicolumn{9}{|l|}{ Rank (percent) } \\
\hline Professor & 33.3 & 65.5 & 29.2 & 59.5 & 43.0 & 63.4 & 63.0 & 84.0 \\
\hline Associate prof. & 45.2 & 25.0 & 36.8 & 29.1 & 26.7 & 23.8 & 26.0 & 12.0 \\
\hline Assistant prof. & 21.4 & 10.0 & 30.2 & 7.4 & 26.7 & 10.6 & 10.0 & 3.0 \\
\hline Other & 0.0 & 0.0 & 3.7 & 4.1 & 3.6 & 2.1 & 1.0 & 1.0 \\
\hline \multicolumn{9}{|l|}{ Sex (percent) } \\
\hline Male & 92.9 & 100.0 & 86.5 & 92.6 & 60.8 & 78.8 & 99.0 & 97.0 \\
\hline Female & 7.1 & 0.0 & 13.5 & 7.4 & 39.2 & 21.1 & 1.0 & 3.0 \\
\hline \multicolumn{9}{|c|}{ Institutional type (percent) } \\
\hline Public research & 48.8 & 42.5 & 22.7 & 14.1 & 16.2 & 17.0 & 42.2 & 26.5 \\
\hline Ind. research & 11.6 & 12.5 & 4.5 & 5.4 & 2.3 & 4.3 & 5.9 & 2.0 \\
\hline Public doctoral & 9.3 & 17.5 & 13.6 & 14.1 & 14.5 & 17.0 & 17.6 & 22.5 \\
\hline Ind. doctoral & 4.7 & 2.5 & 6.4 & 6.7 & 3.5 & 3.8 & 3.9 & 6.9 \\
\hline Public comp. & 16.3 & 17.5 & 39.1 & 39.6 & 49.7 & 44.3 & 23.5 & 28.4 \\
\hline Ind. comp. & 9.3 & 7.5 & 13.6 & 20.1 & 13.9 & 13.6 & 6.9 & 13.7 \\
\hline Mean pgm. grads. & 88 & 88 & 413 & 347 & 273 & 207 & 495 & 325 \\
\hline $\begin{array}{l}\text { Minimum pgm. grads. } \\
\text { Maximum pgm. }\end{array}$ & 4 & 15 & 17 & 20 & 8 & 8 & 14 & 3 \\
\hline grads. & 300 & 300 & 1,299 & 1,299 & 938 & 938 & 1,402 & 1,402 \\
\hline $\begin{array}{r}\text { Mean college } \\
\text { enrollment }\end{array}$ & 17,884 & 18,818 & 12,920 & 11,864 & 12,537 & 13,174 & 22,599 & 16,376 \\
\hline $\begin{array}{l}\text { Minimum college } \\
\text { enrollment }\end{array}$ & 2,851 & 4,072 & 1,477 & 1,477 & 1,592 & 1,840 & 3,227 & 2,967 \\
\hline $\begin{array}{l}\text { Maximum college } \\
\text { enrollment }\end{array}$ & 34,468 & 34,468 & 34,914 & 64,515 & 64,515 & 64,515 & 64,515 & 64,515 \\
\hline
\end{tabular}

${ }^{a}$ On a scale of $0=0 \%$ to $11=100 \%$, some individuals reported slightly more than $100 \%$.

${ }^{b}$ On a scale of $1=$ least important to $7=$ most important. 
TABLE 1. (Continued)

\begin{tabular}{|c|c|c|c|c|c|c|c|c|}
\hline \multirow[b]{2}{*}{ Characteristics } & \multicolumn{2}{|c|}{ Journalism } & \multicolumn{2}{|c|}{ Law } & \multicolumn{2}{|c|}{$\begin{array}{l}\text { Library } \\
\text { Science }\end{array}$} & \multicolumn{2}{|c|}{ Nursing } \\
\hline & $\begin{array}{l}\text { Faculty } \\
N=99\end{array}$ & $\begin{array}{l}\text { Admin } \\
N=87\end{array}$ & $\begin{array}{l}\text { Faculty } \\
N=109\end{array}$ & $\begin{array}{l}\text { Admin. } \\
N=68\end{array}$ & $\begin{array}{l}\text { Faculty } \\
N=92\end{array}$ & $\begin{array}{l}\text { Admin. } \\
N=45\end{array}$ & $\begin{array}{l}\text { Faculty } \\
N=169\end{array}$ & $\begin{array}{l}\text { Admin. } \\
N=126\end{array}$ \\
\hline Percent in role & 53.2 & 46.8 & 61.6 & 38.4 & 67.2 & 32.8 & 57.3 & 42.7 \\
\hline Age & 48.6 & 49.2 & 42.3 & 46.1 & 48.4 & 51.6 & 43.4 & 47.7 \\
\hline Years faculty & 11.7 & 15.1 & 10.8 & 13.4 & 12.2 & 15.5 & 9.2 & 14.0 \\
\hline Teaching time ${ }^{a}$ & 11.7 & 9.3 & 10.0 & 7.2 & 10.3 & 7.3 & 11.9 & 8.1 \\
\hline $\begin{array}{l}\text { Teaching role } \\
\text { important }\end{array}$ & 6.5 & 6.4 & 6.5 & 6.3 & 6.3 & 5.8 & 6.5 & 6.4 \\
\hline $\begin{array}{l}\text { Administrative } \\
\text { role important }^{b}\end{array}$ & 2.2 & 4.5 & 1.7 & 5.2 & 2.1 & 5.2 & 2.8 & 5.6 \\
\hline \multicolumn{9}{|l|}{ Rank (percent) } \\
\hline Professor & 17.9 & 46.0 & 63.0 & 73.5 & 21.1 & 51.5 & 5.9 & 27.8 \\
\hline Associate prof. & 36.8 & 41.4 & 26.9 & 10.3 & 38.9 & 28.9 & 20.1 & 37.3 \\
\hline Assistant prof. & 35.8 & 12.6 & 10.2 & 4.4 & 35.6 & 13.3 & 59.8 & 26.2 \\
\hline Other & 9.6 & 0.0 & 0.0 & 11.8 & 4.4 & 6.6 & 14.3 & 8.7 \\
\hline \multicolumn{9}{|l|}{ Sex (percent) } \\
\hline Male & 82.3 & 89.5 & 78.7 & 85.3 & 48.9 & 57.8 & 4.7 & 4.0 \\
\hline Female & 17.7 & 10.5 & 21.3 & 14.7 & 51.1 & 42.2 & 95.3 & 96.0 \\
\hline \multicolumn{9}{|c|}{ Institutional type (percent) } \\
\hline Public research & 48.0 & 32.2 & 42.2 & 29.4 & 58.7 & 62.2 & 18.8 & 14.3 \\
\hline Ind. research & 9.0 & 8.0 & 10.1 & 13.2 & 10.9 & 8.9 & 2.9 & 7.9 \\
\hline Public doctoral & 8.0 & 24.1 & 20.2 & 23.5 & 20.7 & 13.3 & 14.7 & 16.7 \\
\hline Ind. doctoral & 3.0 & 8.0 & 2.8 & 4.4 & .0 & 0.0 & 5.9 & 4.0 \\
\hline Public comp. & 24.0 & 17.2 & 10.1 & 13.2 & 7.6 & 11.1 & 38.2 & 40.5 \\
\hline Ind. comp. & 8.0 & 10.3 & 14.7 & 16.2 & 2.2 & 4.4 & 19.4 & 16.7 \\
\hline Mean pgm. grads. & 128 & 114 & 236 & 212 & 58 & 67 & 99 & 91 \\
\hline $\begin{array}{l}\text { Minimum pgm. grads. } \\
\text { Maximum pgm. }\end{array}$ & 6 & 3 & 19 & 53 & 5 & 5 & 6 & 10 \\
\hline grads. & 400 & 400 & 586 & 586 & 120 & 350 & 238 & 238 \\
\hline $\begin{array}{l}\text { Mean college } \\
\text { enrollment }\end{array}$ & 23,304 & 17,616 & 20,230 & 16,775 & 24,279 & 24,083 & 14,553 & 13,947 \\
\hline $\begin{array}{l}\text { Minimum college } \\
\text { enrollment }\end{array}$ & 2,088 & 1,592 & 2,560 & 951 & 2,992 & 6,284 & 1,477 & 1,477 \\
\hline $\begin{array}{l}\text { Maximum college } \\
\text { enrollment }\end{array}$ & 64,515 & 64,515 & 64,515 & 48,039 & 64,515 & 64,515 & 64,515 & 64,515 \\
\hline
\end{tabular}


TABLE 1. (Continued)

\begin{tabular}{|c|c|c|c|c|c|c|c|c|}
\hline \multirow[b]{2}{*}{ Characteristics } & \multicolumn{2}{|c|}{ Pharmacy } & \multicolumn{2}{|c|}{ Social Work-UG } & \multicolumn{2}{|c|}{$\begin{array}{l}\text { Social Work- } \\
\text { Grad }\end{array}$} & \multicolumn{2}{|c|}{$\begin{array}{l}\text { Combined Field } \\
\text { Sample }\end{array}$} \\
\hline & $\begin{array}{l}\text { Faculty } \\
N=29\end{array}$ & $\begin{array}{l}\text { Admin. } \\
N=57\end{array}$ & $\begin{array}{l}\text { Faculty } \\
N=64\end{array}$ & $\begin{array}{l}\text { Admin. } \\
N=61\end{array}$ & $\begin{array}{l}\text { Faculty } \\
N=25\end{array}$ & $\begin{array}{l}\text { Admin } \\
N=31\end{array}$ & $\begin{array}{l}\text { Faculty } \\
N=313\end{array}$ & $\begin{array}{l}\text { Admin. } \\
N=280\end{array}$ \\
\hline Percent in role & 33.7 & 66.3 & 51.2 & 48.8 & 44.6 & 55.4 & 52.8 & 47.2 \\
\hline Age & 45.0 & 47.7 & 45.6 & 47.1 & 50.0 & 52.7 & 46.5 & 49.1 \\
\hline Years faculty & 15.2 & 18.0 & 10.6 & 12.9 & 15.0 & 15.5 & 12.9 & 16.0 \\
\hline Teaching time $^{a}$ & 10.3 & 7.6 & 11.7 & 9.4 & 10.4 & 7.6 & 10.9 & 8.2 \\
\hline \multicolumn{9}{|l|}{ Teaching role } \\
\hline $\begin{array}{l}\text { Administrative } \\
\text { role important }{ }^{b}\end{array}$ & 2.1 & 5.3 & 2.1 & 5.1 & 3.2 & 5.2 & 2.2 & 5.1 \\
\hline \multicolumn{9}{|l|}{ Rank (percent) } \\
\hline Professor & 46.4 & 56.9 & 15.4 & 24.6 & 45.8 & 61.3 & 35.2 & 57.9 \\
\hline Associate prof. & 28.6 & 31.0 & 32.3 & 49.2 & 33.3 & 25.8 & 29.6 & 26.4 \\
\hline Assistant prof. & 25.0 & 5.2 & 41.5 & 24.6 & 20.8 & 6.5 & 29.6 & 9.3 \\
\hline Other & 0.0 & 6.8 & 10.7 & 1.6 & 0.0 & 6.4 & 5.5 & 5.7 \\
\hline \multicolumn{9}{|l|}{ Sex (percent) } \\
\hline Male & 82.8 & 91.4 & 44.6 & 63.9 & 54.2 & 51.6 & 65.9 & 77.3 \\
\hline Female & 17.2 & 8.6 & 55.4 & 36.1 & 45.8 & 48.4 & 34.1 & 22.7 \\
\hline \multicolumn{9}{|c|}{ Institutional type (percent) } \\
\hline Public research & 58.6 & 55.2 & 20.0 & 11.5 & 48.0 & 58.1 & 39.6 & 31.8 \\
\hline Ind, research & 0.0 & 5.2 & 1.5 & 1.6 & 8.0 & 32.2 & 6.7 & 9.6 \\
\hline Public doctoral & 17.2 & 17.2 & 24.6 & 14.8 & 36.0 & 9.7 & 19.2 & 15.7 \\
\hline Ind. doctoral & 3.4 & 6.9 & 0.0 & 3.3 & 4.0 & 0.0 & 1.6 & 1.8 \\
\hline Public comp. & 17.2 & 8.6 & 43.1 & 54.1 & 4.0 & 0.0 & 23.3 & 26.4 \\
\hline Ind. comp. & 3.4 & 6.9 & 10.8 & 14.8 & 0.0 & 0.0 & 9.6 & 14.6 \\
\hline Mean pgm. gras & 96 & 87 & 42 & 33 & 122 & 122 & & \\
\hline Minimum pgm. grads. & 37 & 28 & 6 & 5 & 15 & 1 & & \\
\hline $\begin{array}{l}\text { Maximum pgm. } \\
\text { grads. }\end{array}$ & 160 & 160 & 139 & 100 & 296 & 296 & & \\
\hline $\begin{array}{r}\text { Mean college } \\
\text { enrollment }\end{array}$ & 21,708 & 22,176 & 17,688 & 13,016 & 23,009 & 21,614 & & \\
\hline $\begin{array}{l}\text { Minimum college } \\
\text { enrollment }\end{array}$ & 5,997 & 5,997 & 1,968 & 1,968 & 8,230 & 4,525 & & \\
\hline $\begin{array}{l}\text { Maximum college } \\
\text { enrollment }\end{array}$ & 42,230 & 64,515 & 48,039 & 48,039 & 64,515 & 32,826 & & \\
\hline
\end{tabular}


nursing and in social work graduate programs, were more likely to be male than female. Since these variations tend to be characteristic of the fields rather than due to sampling error, no attempts were made to control for them in the analysis.

In order to use equal numbers of respondents for each field for comparative analysis in this study, 60 respondents were drawn at random from each professional field to constitute a "combined field" sample. Subsequent deletion of respondents with missing data on any of the variables reduced the sample available for the combined field analyses to 313 faculty members and 280 administrators. The sample reductions due to missing data are offset, to some extent, by the large numbers of respondents from which the analysis sample could be randomly selected.

Where initial results merited further exploration of different views among faculty and administrators within professional fields, all nonmissing responses from the entire data base were analyzed to ensure ample subsamples.

\section{The Dependent Variables}

Dependent variables were four factor scores representing perceived influence on the professional field and program. As described earlier, based on a study of professional education literature, potential influences on professional preparation programs had been grouped a priori to represent four sets of influences: external societal influences ( 9 items), external professional community influences ( 8 items), intraorganizational influences (6 items), and internal influences (14 items). Perceived intensity of curricular debates was used as a proxy for internal influences on professional programs.

Post hoc factor analysis of responses to all thirty-seven influence items using the original data base $(N=2,217)$ had confirmed the relative independence of societal, professional community, intraorganizational, and internal influence sets. (Stark et al., 1987). The factor loadings presented in Table 2 were obtained from subsequent separate factor analyses of each dimension followed by varimax rotation. The factor intercorrelations for the broad data sample used in this study $(1,722$ respondents classified as 849 faculty members and 873 administrators) are also given in table 2 .

\section{The Covariates}

Since professional programs are not similarly distributed among various types of institutions, and since differences in faculty and administrator views by institutional type as well as by college and program size have been reported (Whitson and Hubert, 1982; Madron et al., 1976), these program characteristics were entered first in each regression analysis as covariates. The annual number 
TABLE 2. Characteristics of Factor Scores Used in Analysis

\begin{tabular}{|c|c|c|c|c|}
\hline Survey Item & $\begin{array}{c}\text { Societal } \\
\text { Influence } \\
N=2,080\end{array}$ & $\begin{array}{c}\text { Professional } \\
\text { Influence } \\
N=2,131\end{array}$ & $\begin{array}{c}\text { Intra- } \\
\text { organizational } \\
\text { Influence } \\
N=2,154\end{array}$ & $\begin{array}{c}\text { Internal } \\
\text { Influence } \\
N=2,114\end{array}$ \\
\hline Ample rewards for graduates & .68 & & & \\
\hline Ample jobs for graduates & .42 & & & \\
\hline Media portrayal positive & .55 & & & \\
\hline Federal policies supportive & .72 & & & \\
\hline State policies supportive & .59 & & & \\
\hline Private policies supportive & .78 & & & \\
\hline Government funding adequate & .65 & & & \\
\hline Private funding adequate & .66 & & & \\
\hline Licensing adequate ${ }^{a}$ & - & & & \\
\hline Field has knowledge consensus & & .42 & & \\
\hline Practice setting available & & .34 & & \\
\hline Accrediting is rigorous & & .88 & & \\
\hline Accrediting is enforced & & .85 & & \\
\hline Prof. controls number of grads. ${ }^{a}$ & & - & & \\
\hline Field has ethics consensus & & .51 & & \\
\hline Publications have impact & & .43 & & \\
\hline Alumni influence program ${ }^{a}$ & & - & & \\
\hline Program central to university & & & .81 & \\
\hline Program interrelated with others & & & .53 & \\
\hline $\begin{array}{l}\text { Univ. provides ample financial } \\
\text { support }\end{array}$ & & & .70 & \\
\hline Univ. governance facilities & & & .78 & \\
\hline Program generates income ${ }^{a}$ & & & - & \\
\hline Program produces prestige ${ }^{a}$ & & & .40 & \\
\hline Instructional methods & & & & .64 \\
\hline Balance theory/practice & & & & .70 \\
\hline Function of practicum & & & & .67 \\
\hline Content of professional core & & & & .68 \\
\hline Content of foundational studies & & & & .67 \\
\hline Content of related studies & & & & .59 \\
\hline $\begin{array}{l}\text { Integration of professional/ } \\
\text { foundational studies }\end{array}$ & & & & .66 \\
\hline Program length & & & & .59 \\
\hline Course sequencing & & & & .68 \\
\hline Program evaluation & & & & .71 \\
\hline Evaluation of students & & & & .68 \\
\hline
\end{tabular}


TABLE 2. (Continued)

\begin{tabular}{lcccc}
\hline & $\begin{array}{c}\text { Societal } \\
\text { Influence }\end{array}$ & $\begin{array}{c}\text { Professional } \\
\text { Influence }\end{array}$ & $\begin{array}{c}\text { Intra- } \\
\text { organizational } \\
\text { Influence }\end{array}$ & $\begin{array}{c}\text { Internal } \\
\text { Influence }\end{array}$ \\
Survey Item & $N=2,080$ & $N=2,131$ & $N=2,154$ & $N=2,114$ \\
\hline $\begin{array}{l}\text { Admissions requirements } \\
\text { Number of graduates }\end{array}$ & & & & .62 \\
$\begin{array}{l}\text { Provide continuing education } \\
\text { Eigenvalue }\end{array}$ & & & & .52 \\
$\begin{array}{l}\text { Percent variance explained } \\
\text { Kaiser statistic }\end{array}$ & 30.6 & 22.3 & 27.1 & .61 \\
$\begin{array}{l}\text { Intercorrelations }(N=1,722) \\
\text { Societal influence }\end{array}$ & .60 & .68 & .49 & .70 \\
$\begin{array}{l}\text { Professional influence } \\
\text { Intraorganizational influence }\end{array}$ & - & & & .24 \\
\hline
\end{tabular}

${ }^{a}$ Not included in factor score.

of program graduates in 1984, as reported by the institution's registrar, was used as the measure of program size. The 1982-83 institutional enrollment served as the measure of institutional size, and a dichotomous dummy variable was included for institutional type (research and doctoral institutions $=1$; comprehensive colleges $I=0$ ). The correlations between program size and the other two covariates were small. Although the correlation between institutional size and institutional type was substantial (.62), a check for multicollinearity produced a maximum squared multiple correlation among the three covariates of .39 , and all variables were retained in the analysis for control purposes. Table 3 gives the intercorrelation matrix among variables used in the analysis. Although these bivariate correlations are small in magnitude, they suggest that faculty and administrator differences may occur with respect to strength of professional community influences and intraorganizational influences and that the chosen covariates, program size, institutional size, and institutional type, are moderately related to the dependent variables.

\section{RESULTS}

To answer the first research question regarding whether faculty members and administrators differ in their perceptions of the four influences, the first analysis used the combined field sample of responses with equal representation from each professional field. Of the 593 cases designated as either faculty or administrators, 503 individuals had responded un all variables. Summary results of the four hierarchical regression analyses are shown in Table 4. 
TABLE 3. Correlation Matrix of Covariates, Predictor Variables, and Dependent Variables

\begin{tabular}{lcccc}
\hline Variables & $\begin{array}{c}\text { Institution } \\
\text { Type }\end{array}$ & $\begin{array}{c}\text { Program } \\
\text { Size }\end{array}$ & $\begin{array}{c}\text { Institution } \\
\text { Size }\end{array}$ & $\begin{array}{c}\text { Academic } \\
\text { Role }\end{array}$ \\
\hline Program size & $.15^{*}$ & & & \\
Institution size & $.62^{*}$ & $.25^{*}$ & & \\
Academic role & $.11^{*}$ & .04 & $.16^{*}$ & \\
Societal influence & $-.09^{*}$ & $.22^{*}$ & -.03 & -.06 \\
Prof. community influence & $-.10^{*}$ & -.06 & $-.09^{*}$ & $-.11^{*}$ \\
Intraorganizational influence & $-.14^{*}$ & -.00 & $-.10^{*}$ & $-.18^{*}$ \\
Internal influence & -.00 & .01 & .01 & .02 \\
\hline
\end{tabular}

Note: Correlations were computed from cases with nonmissing responses $(N=503)$ of random equal samples from each professional field.

$* p<.05$.

The covariates accounted for very little variance in any of the four dependent variables. Addition of faculty/administrative role to the regression equation resulted in a statistically significant increase in $R$-square $(p<.05)$ when the professional community or intraorganizational factor scores were the dependent variables, but not in the regressions for societal influences or curriculum debates.

In general, the variance in the dependent variables accounted for by the covariates plus the independent variable, faculty/administrative role, was very small. Subsequently, a set of dummy variables based on program identity was entered into the equation, once before, and once following, the role variable. In three of the four equations, the percent of variance explained was increased substantially by the addition of program identity but remained small for all equations. The pattern of changing variance exhibited by the four equations when independent predictors were entered in different orders (See Table 4) indicates that faculty and administrative perceptions of external societal influences differ more substantially by professional field than by academic role. In contrast, perceptions of intraorganizational influence are predicted better by academic role than by professional field membership. Perceptions regarding professional community influence are predicted significantly but very slightly by professional field, while internal influence, at least as exemplified in perceptions of on-going debates, is predicted neither by role nor field.

The factor scores representing intraorganizational influence were regressed upon the covariates and faculty/administrative role separately for respondents in each of the eleven professional programs. As shown in Table 5, in six of the eleven fields (education, engineering, journalism, law, library science, nursing), predictions of intraorganizational influence based on academic role 
TABLE 4. Summary of Regression of Influence Factors on Control Variables, Program Identification, and Faculty/Administrative Role $(N=\mathbf{5 0 3})$

\begin{tabular}{|c|c|c|c|c|c|}
\hline Influence & $F$ & $d f$ & Mult $-R$ & $R$-Sqr. & $\begin{array}{l}\text { Increase } \\
\text { in } R \text {-Sqr }\end{array}$ \\
\hline \multicolumn{6}{|l|}{ Societal Influence } \\
\hline Control variables & $11.23 *$ & 3,499 & .25 & .063 & \\
\hline Control variables plus role & $8.79 *$ & $4,1,498$ & .26 & .066 & \\
\hline \multicolumn{6}{|l|}{ Control variables, role, and } \\
\hline Attributable to role after program & 1.44 & $14,1,488$ & & & \\
\hline Attributable to program after role & 31.28 & $14,10,488$ & & & $* *$ \\
\hline \multicolumn{6}{|l|}{ Professional Community Influence } \\
\hline Control variables & 2.14 & 3,499 & .11 & .013 & \\
\hline Control variables plus role & $2.70^{*}$ & $4,1,498$ & .15 & .021 & $* *$ \\
\hline \multicolumn{6}{|l|}{ Control variables, role, and } \\
\hline program identification & $5.82 *$ & 14,488 & .38 & .140 & $* *$ \\
\hline Attributable to role after program & 3.12 & $14,1,488$ & & & \\
\hline Attributable to program after role & 6.93 & $14,10,488$ & & & ** \\
\hline \multicolumn{6}{|l|}{ Intraorganizational Influence } \\
\hline Control variables & $3.43 *$ & 3,499 & .14 & .017 & \\
\hline Control variables plus role & $6.38 *$ & $4,1,498$ & .22 & .049 & ** \\
\hline \multicolumn{6}{|l|}{ Control variables, role, and } \\
\hline program identification & $4.16^{*}$ & 14,488 & .33 & .110 & \\
\hline Attributable to role after program & $12.79 *$ & $14,1,488$ & & & ** \\
\hline Attributable to program after role & $3.16^{*}$ & $14,10,488$ & & & ** \\
\hline \multicolumn{6}{|l|}{ Internal Influence } \\
\hline Control variables & 0.04 & 3,499 & .02 & .000 & \\
\hline Control variables plus role & 0.09 & $4,1,498$ & .03 & .000 & \\
\hline \multicolumn{6}{|l|}{ Control variables, role, and } \\
\hline program identification & 1.53 & 14,488 & & & $* *$ \\
\hline Attributable to role after program & .24 & $14,1,488$ & & & \\
\hline Attributable to program after role & 2.10 & $14,10,488$ & & & $* *$ \\
\hline
\end{tabular}

* $F$ ratio for regression equation is significant at .05 .

** Addition of variable produces significant increase $(p<.05)$ in $R$-square.

were statistically significant but very weak. Specifically, administrators perceived these influences as very slightly stronger than did faculty members.

We speculated that academic administrators would perceive external influences on the program as stronger than would faculty members. This speculation was not substantively supported by the data. In fact, particularly for external influences originating in society at large, variations are more closely 


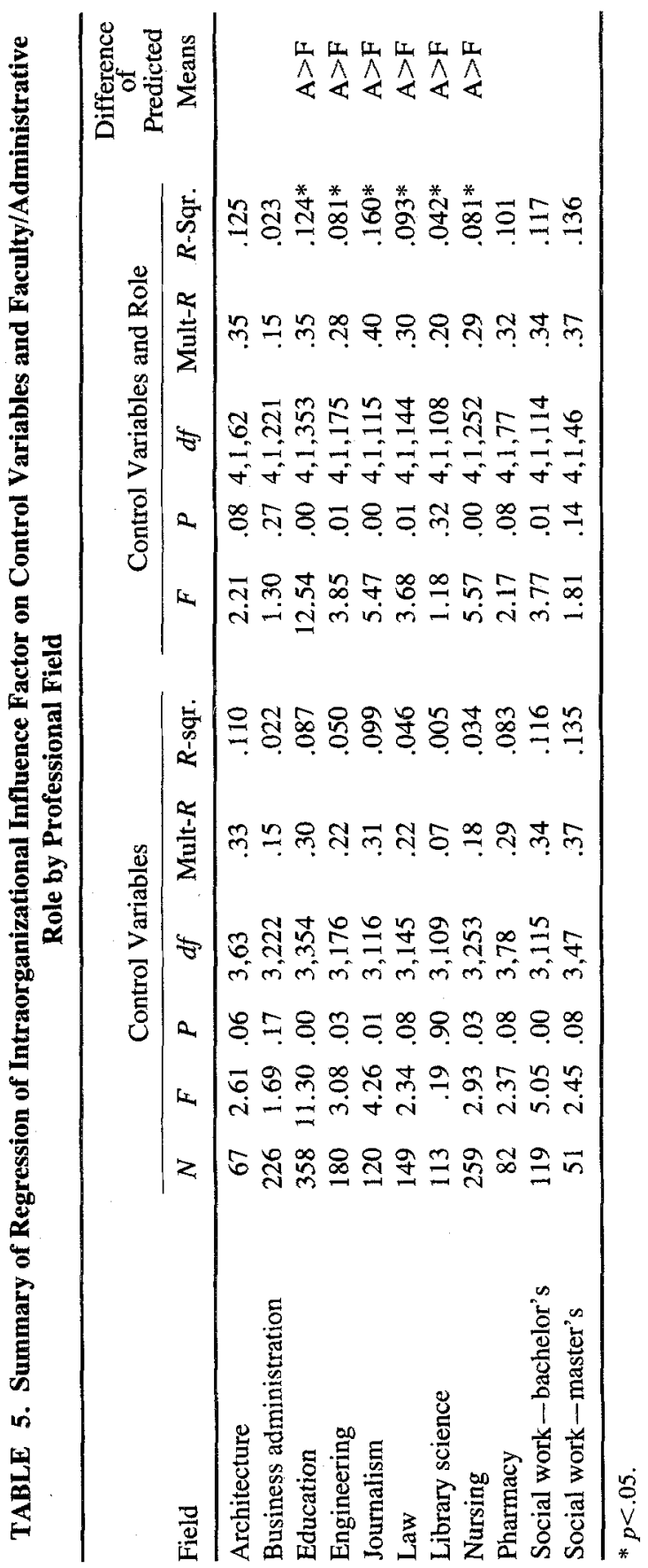


related to professional field membership than to academic role played. Differences in how faculty and administrators within fields view the influence of their professional community also are minor. As we reported in a previous analysis, the extent to which society is viewed as supportive varies widely by field (Stark et al., 1987), and administrators and faculty seem to share a common view of their field's status.

Our hypothesis that academic administrators would perceive stronger intraorganizational influences (from within the university but outside the program) received modest support. In six of eleven fields, administrators tended to perceive intrauniversity influences as slightly stronger than did faculty members. Since the wording of the influence items suggested either support from or significant contribution to the institution, one can interpret administrator views in the identified fields as slightly more positive toward intrauniversity relationships than the views of faculty generally.

We assumed that faculty members would report stronger internal influence, indicated in this survey by sensing and reporting a more active level of curriculum debate, than would academic administrators. This assumption was not supported; indeed, the absence of different views on any aspect of curriculum debate by academic role or by professional field was striking.

Finally, the data provided limited support for our surmise that patterns of faculty-administrator would vary among fields. Analysis of aggregated data suggested that faculty and administrators, overall, would likely disagree primarily about intraorganizational influences on their programs. Closer analysis by field revealed that the relatively small differences between individuals in the two roles may be field-specific.

Several limitations of the study must be noted in interpreting the results. First, the faculty members selected by administrators to respond to the survey may hold views more similar to those of administrators than would faculty members selected randomly. Second, faculty members holding varied administrative titles may have different levels of involvement in external and intrauniversity affairs. Third, in order to gain a broad picture of professional preparation, data from a wide variety of programs and institutions were analyzed. The use of statistical controls to eliminate variance due to program and institutional characteristics artificially equalized relationships that may be important in actual situations. Each of these sample limitations may partly explain poor predictive power of the regression equations. While very little variance in the dependent measures was attributed to the covariates that we attempted to control, only modest additional variance was explained by the independent variables of interest.

\section{DISCUSSION}

Our discussion initially will focus on two findings: (1) failure to identify expected differences between faculty and administrator views of external 
influences; and (2) identification of slight differences between faculty and administrator views in several fields with respect to intraorganizational influences. Subsequently, we will suggest some implications of these results for the administrative role.

\section{Common Views on External Influences}

Contrary to our speculations, academic administrators in professional fields seemed no more sensitive to potential external influences on their programs than faculty members. Possible explanations include the following: (1) program level academic administrators in professional fields devote no more time and attention to external linkages than do faculty; (2) within their specific fields faculty members and administrators have been socialized to a common view of the field's relation to its societal and professional environment; or (3) administrators and faculty are doing an effective job of communicating about external influences.

In the aggregate, our data seem to support the first explanation, namely, that academic administrators do not readily accept or perform the adaptive maintenance role, or at least that the role does not alter their views. This explanation is also supported by reports that academic administrators consider the effort required to link with nonuniversity environment unwise compared to continuing their academic endeavors (McLaughlin et al., 1975) and that chairpersons believed their tasks were rarely influenced by external forces (Whitson and Hubert, 1982).

Our finding that field differences account for far greater variation in views of external influences than does role played supports the second explanation, that professional field faculty are socialized to a common view. Since relative consensus exists about each professional program's place in its external setting, the field may shape attitudes and behavior of both faculty and administrators more than does the specific role played. Nonetheless, since we gathered no data on how the views expressed in the survey became similar, we cannot dismiss the third explanation - that consensus may result from effective communication flow from administrators to faculty members, or the reverse.

Although external influence perceptions appear not to be a source of potential conflict within specific fields, there is much to learn about the ways in which professional program administrators might link their programs with the external environment. Within fields, it would seem useful to identify and examine programs where administrators place very different amounts of emphasis on external linkages. How do such programs differ, in internal consensus, in intraorganizational relationships, and in independent measures of effectiveness?

\section{Differing Views on Intraorganizational Influences}

Faculty and administrators in six of eleven types of programs held slightly different assessments of the strength of influences on their programs arising 
from within the university. The measure of external influence used in this study may be viewed as beyond local control while the issues that formed the measure of internal curriculum influence fall easily within program purview. In contrast to these extremes, the intraorganizational influence measure used in this study was characterized by relationships between organizational levels that are close at hand but difficult to alter. The five items contributing to the measure dealt with (1) centrality of the program to the university (or college) mission, (2) extent of interconnectedness with other academic programs, (3) adequacy of financial support by the university, (4) facilitative nature of governance patterns, and (5) contribution of the program to the prestige of the university. Since all items were worded in a positive direction, one interpretation is that in some programs, administrators were slightly more positive about university supportiveness than faculty members, while in other programs faculty and administrators held similar assessments of institutional support. In no field did administrators have less positive views on intraorganizational relationships than faculty.

We submit two possible explanations for the more positive view of administrators. The first is that the administrative view is a more accurate assessment of on-campus relationships; the second is that administrators are constrained to think positively, thus avoiding dissonance and role conflict. For example, faculty members may more easily attribute perceived lack of support within the university to the failure of others than themselves. Program administrators must accept heavy responsibility for these relationships.

We can offer no reason why faculty and administrator views should differ slightly in education, engineering, journalism, law, library science, and nursing but not in architecture, business, pharmacy, and social work. This division into two sets of fields based on consensus does not correspond to any other dimension we have examined in our survey data. For example, the division does not occur along lines of faculty perceptions of strong societal or professional community support, of intensity of curricular debates, or of gender distribution characteristic of the fields. Nationally, at the time of the survey some fields in each set were threatened by national criticism, declining enrollment, oversupply or program reduction while in other fields the opposite trends and conditions were true. Finally, each set contains fields with diverse paradigms and service orientations.

\section{Implications}

Within the limitations of this study, a picture emerges of relative consensus among professional field faculty and administrators about various external influences that affect their programs and about current internal curricular discussions. The arena of program/university relationships, however, seems a likely site for conflicting views and thus, as was highlighted by our literature 
review, such conflicts may continue to hold more interest for researchers than educational views within programs.

Observers have criticized the readiness of academic administrators moving into their positions directly from the faculty to provide necessary leadership with respect to a variety of contextual issues. Whether the most important focus to help administrators develop effective strategies is on external or intraorganizational contextual issues may depend upon temporal conditions characteristic of each professional field. While in some cases assistance with scanning and responding to the environment is important, in other cases, administrators may be better served to concentrate on building relationships among organizational levels within the university. For professional programs, particularly, the important administrator role as the "person in the middle" may center not on relating the program to the external environment or on building consensus among the faculty. Rather, the important "bridge builder" role may be to interpret and represent the unique consensus about education for the professional field in university forums where shares of university funds, power, and prestige are determined.

Acknowledgments. The authors thank Maurice Marchant, Brigham Young University, and Pamela Lokken, University of Michigan, for their helpful comments.

\section{REFERENCES}

Bennett, J. B. (1983). Managing the Academic Department. New York: Macmillan.

Gross, E., and Grambsch, P. V. (1974). Changes in University Organization, 1964-1971. New York: McGraw Hill.

Jennerich, E. J. (1981). Competencies for department chairpersons: myths and realities. Liberal Education 67: 46-60.

Katz, D. and Kahn, R. (1966). The Social Psychology of Organizations. New York: Wiley.

Knight, W. H., and Holen, M. C. (1985). Leadership and the perceived effectiveness of department chairpersons. Journal of Higher Education 56(6): 677-690.

Madron, T. W., Craig, J. R., and Mendel, R. M. (1976). Departmental morale as a function of the perceived performance of department heads. Research in Higher Education 5: 83-94.

McLaughlin, G. W., Montgomery, J. R., and Malpass, L. F. (1975). Selected characteristics, roles, goals, and satisfactions of department chairmen in state and land-grant institutions. Research in Higher Education 3: 243-259.

McLughlin, G. W., Montgomery, J. R., and Sullins, W. R. (1977). Roles and characteristics of department chairmen in state universities as related to level of decision making. Research in Higher Education 6: 327-341.

Ryan, D. W. (1980). Deans as individuals in organizations. In Griffith, D. and McCarty, D., The Dilemma of the Deanship, pp. 133-176. Danville, IL: Interstate Printers and Publishers.

Smart, J., and Elton, C. (1976). Administrative roles of department chairmen. In J. C. 
Smart and J. R. Montgomery (eds.), Examining Departmental Management. (New Directions for Institutional Research No. 10), pp. 39-60. San Francisco: Jossey Bass. Stark, J. S. (1986). Administrator and faculty views of role performance. In J. W. Creswell (ed.), Measuring Faculty Research Performance. (New Directions for Institutional Research No. 50), pp. 59-74. San Francisco: Jossey-Bass.

Stark, J. S., Lowther, M. A., and Hagerty, B. M. K. (1987). Faculty perceptions of professional preparation environments: Testing a conceptual framework. Journal of Higher Education 58 (5): 530-559.

Stark, J. S., Lowther, M. A., and Hagerty, B. M. K. (1986a). Faculty roles and role perceptions in ten professional fields. Research in Higher Education 25(1): 3-30.

Stark, J. S., Lowther, M. A., Hagerty, B. M. K., and Orcyzk, C. (1986b). A conceptual framework for the study of preservice professional preparation programs in colleges and universities. Journal of Higher Education 57(3): 231-258.

Tucker, A. (1984). Chairing the Academic Department: Leadership Among Peers. 2nd edition. New York: Macmillan.

Whitson, L. J., and Hubert, F. W. R. (1982). Interest groups and the department chairperson. Journal of Higher Education 53(2): 163-176.

Zey-Ferrell, M., and Ervin, D. (1985). Achieving congruent actions and intentions: An empirical assessment of faculty work in a regional public university. Research in Higher Education 22(4): 347-369.

Received June 26, 1987 